\title{
POLYMERIZATION OF A DUAL-CURED CEMENT THROUGH CERAMIC: LED CURING LIGHT VS HALOGEN LAMP
}

\author{
POLIMERIZAÇÃO DE UM CIMENTO RESINOSO DUAL ATRAVÉS DE UMA PORCELANA: \\ LED VS LÂMPADA HALÓGENA
}

\author{
Lawrence Gonzaga LOPES' ${ }^{1}$, Eduardo Batista FRANCO ${ }^{2}$, Abrão Name NETO ${ }^{3}$, Francyle S. HERRERA ${ }^{3}$, \\ Cristina KURACHI ${ }^{4}$, Juan C. CASTAÑEDA-ESPINOSA ${ }^{5}$, José Roberto Pereira LAURIS ${ }^{6}$
}
1- DDS, MSc, PhD, Assistant Professor, Department of Operative Dentistry, Brasília Catholic University, Taguatinga, Distrito Federal, Brasília.
2- DDS, MSc, PhD, Associate Professor, Department of Operative Dentistry, Endodontics and Dental Materials, Bauru Dental School,
University of São Paulo, Bauru, SP, Brazil.
3- DDS , Undergraduate student, Department of Operative Dentistry, Endodontics and Dental Materials, Bauru Dental School, University of São Paulo, Bauru, SP, Brazil.
4- DDS, MSc, PhD , Dentist, São Carlos Institute of Physics, University of São Paulo, São Carlos, SP, Brazil.
5- DDS, MSc, Graduate student (Doctor degree), Department of Operative Dentistry, Endodontics and Dental Materials, Bauru Dental School, University of São Paulo, Bauru, SP, Brazil.
6- DDS, MSc, PhD, Assistant Professor, Department of Pediatric Dentistry, Orthodontic and Collective Health, Bauru Dental School, University of São Paulo, Bauru, SP, Brazil

\begin{abstract}
Corresponding address: Dr. Eduardo B. Franco, Department of Operative Dentistry, Endodontics and Dental Materials, Bauru Dental School, University of São Paulo. Al. Octávio Pinheiro Brizola 9-75, Cep.: 17012901, Bauru-SP, Brazil. Tel: 55142358265 , Fax: 5514235 8325. E-mail: ebfranco@fob.usp.br
\end{abstract}

Received: February 17, 2004 - Returned for reformulation: April 23, 2004 - Accepted: September 22, 2004

\begin{abstract}
$T_{\text {h }}$

Le aim of this study was to investigate the influence of light source, LED unit and halogen lamp (HL), on the effectiveness of Enforce dualcured cement cured under a ceramic disc. Three exposure times (60, 80 and $120 \mathrm{~s}$ ) were also evaluated. Two experimental groups, in which the polymerization of the dual-cured cement was performed through a ceramic disc, and two control groups, in which the polymerization of the dualcured cement was performed directly without presence of ceramic disc were subdivided into three subgroups (three different exposure times), with five specimens each: G1A- HL 60s; G1B- HL 80s; G1C- HL 120s; G2A- LED 60s; G2B- LED 80s; G2C- LED 120s; and control groups: G3A- HL 60s; G3B- HL 80s; G3C- HL 120s; G4A- LED 60s; G4B- LED 80s and G4C- LED 120s. Cement was applied in a steel matrix (4mm diameter, $1.2 \mathrm{~mm}$ thickness). In the experimental groups, a ceramic disc was placed on top. The cement was light-cured through the ceramic by a HL and LED, however, the control groups were cured without the ceramic disc. The specimens were stored in a light-proof container at $37^{\circ} \mathrm{C}$ for 24 hours, then Vickers hardness was determined. A four-way ANOVA and Tukey test ( $\mathrm{p} £ 0.05$ ) were performed. All specimens cured by LED for 60s showed inferior values compared with the halogen groups. In general, light-curing by LED for 80s and 120s was comparable to halogen groups (60s and 80 s) and their control groups. LED technology can be viable for light-curing through conventional ceramic indirect restorations, when curing time is increased in relation to HL curing time.

Uniterms: Resin cements; Microhardness test; Dental ceramic; Light emitting diode.
\end{abstract}

\section{RESUMO}

objetivo deste estudo foi estudar a influência da fonte de luz, LED e lâmpada halógena (LH), na efetividade de polimerização do cimento resinoso dual Enforce fotoativado sob um disco de porcelana. Três tempos de exposição (60, 80 e 120 segundos) foram também avaliados. Dois grupos experimentais, na qual a polimerização do cimento resinoso foi feita através de um disco cerâmico, e dois controles, polimerização direta do cimento, sem presença do disco cerâmico foram subdivididos em três subgrupos, com cinco amostras em cada: G1A- LH 60s; G1B- LH 80s; G1CLH 120s; G2A- LED 60s; G2B- LED 80s; G2C- LED 120s; e grupos controles: G3A- LH 60s; G3B- LH 80s; G3C- LH 120s; G4A- LED 60s; G4BLED 80s e G4C- LED 120s. O cimento resinoso foi inserido em uma matriz de aço (4 mm de diâmetro e 1,2 mm de espessura). Nos grupos experimentais um disco de porcelana (6 mm de diâmetro por $2 \mathrm{~mm}$ de espessura) foi colocado sobre o cimento. Este foi fotoativado através da porcelana pela lâmpada halógena e pelo LED, por outro lado nos grupos controles a luz foi aplicada sem o disco de porcelana. As amostras foram armazenadas em um frasco que impedia a passagem de luz a $37^{\circ} \mathrm{C}$ por 24 horas, para que depois a dureza Vickers fosse determinada. Os dados foram submetidos à análise de variância a quatro critérios seguido pelo teste Tukey (p£ 0,05). Todas as amostras polimerizadas pelo LED por 60s mostraram valores inferiores quando comparadas com as do grupo da lâmpada halógena. Em geral, a fotoativação realizada por 80 e 120 s com o LED foi estatisticamente similar à fotoativação com a lâmpada halógena (60 e 80 s). A tecnologia LED pode ser viável para a fotoativação de restaurações indiretas de porcelana quando o tempo de polimerização é aumentado.

Unitermos: Cimento resinoso; Teste de dureza; Porcelanas; LED. 


\section{INTRODUCTION}

A growing demand for esthetic restorative materials has occurred greatly in recent years ${ }^{11}$. This was due to the greater knowledge of patients about the new technologies in Dentistry and the improvement of the physical properties of esthetic materials. Thus, ceramic inlays, onlays and crowns have been advocated as an alternative to solve, esthetically and functionally, some clinical problems ${ }^{2,22}$.

Polymerization of the resin cement is related with the success of these types of indirect restorations, since a high degree of conversion is desirable for a resin cement, which can guarantee adequate mechanical properties as low solubility and high biocompatibility ${ }^{2,7}$. Additionally, these properties can provide a reliable and more durable bond between indirect restorations and dental tissues ${ }^{2,11}$.

Traditionally, quartz tungsten halogens (QTH) lights have been widely employed for light-curing of resin materials ${ }^{5}$. These units provide a wide spectral output and require a dielectric pass-band filter that removes the undesirable wavelengths under 400nm and over 500 $\mathrm{nm}^{4,20}$. However, the light spectrum of this equipment is still much wider than the 450-490nm required for camphorquinone, inducing heat radiation ${ }^{5,10,15}$. Consequently, this heat leads to a decline of irradiation over time due to degradation of the bulb and filter ${ }^{5,10}$. A recent new technology, light-emitting diode (LED), has been proposed as an alternative for conventional QTH lights ${ }^{8,16,23}$. LED units emit blue visible light in a narrow bandwidth (450-490nm) that corresponds closely with the absorption peak of camphorquinone, the most commonly used photoinitiator in light-activated materials ${ }^{1,8}$. Because of this, no filter systems are required and heat produced is lower than conventional $\mathrm{QTH}^{1,8,10}$. An additional advantage of using LED would be the long lifetime and low-cost technology $y^{1,8,10}$.

A recent series of papers have indicated LED units as a viable light source for light-curing of direct resin restorations, especially with increment thickness of about $2 \mathrm{~mm}^{1,8,10,13,16}$. However, when general practitioners buy a light-curing unit, they will use it for both direct and indirect clinical situations. Thus, studies that simulate conditions where the light must pass through a ceramic to activate the resin cement are very important, since the ceramic indirect restorations are considered a common clinical procedure in modern operative dentistry. Therefore, the aim of this study was to evaluate the hardness of a dual-cured resin cement under a ceramic disc after light-curing with LED lightactivation unit and conventional QTH unit. Three exposure times (60, 80 and 120s) were also investigated.

\section{MATERIALS AND METHODS}

The materials and curing units used in this study are shown in Table 1. This study evaluated the hardness of Enforce dual-cured resin cement (with camphorquinone as photoinitiator) when light-cured through a ceramic disc (Duceram - conventional ceramic) by LED curing unit or halogen conventional curing unit. Two experimental groups, in which curing of the dual-cured cement was performed through a ceramic disc, and two control groups, in which the polymerization of the dual-cement was performed directly without presence of ceramic disc were established. Each group was subdivided into three subgroups in accordance with three exposure times (60, 80 and 120s). These exposure times were selected because they are generally used and recommended for polymerization of indirect restorations ${ }^{9,12}$. The groups tested are shown in Table 2.

\section{Specimen preparation}

The base and catalyst of the resin cement were mixed following the manufacturer's instructions and inserted into a stainless steel matrix with a cylindrical-shaped perforation measuring $4 \mathrm{~mm}$ in diameter and $1.2 \mathrm{~mm}$ in thickness (Figure 1). A clear Mylar strip was placed over and under the resin cement, and a Duceram ceramic disc (Ducera, Degussa Dental, Germany) measuring $6 \mathrm{~mm}$ in diameter and $2 \mathrm{~mm}$ in thickness was placed over the resin cement. This thickness of the ceramic disc was selected because it is compatible with ceramic indirect restorations such as inlays, onlays or crowns. The resin cement was light-cured through the ceramic by a QTH unit (XL 2500, 3M, São Paulo, Brazil) and LED unit (Ultraled, Ribeirão Preto, SP, Brazil) for exposure times of 60,80 and 120 s. The halogen and LED light intensities were $760 \mathrm{~mW} / \mathrm{cm}^{2}$ and $130 \mathrm{~mW} / \mathrm{cm}^{2}$, respectively. These power measurements were obtained using a calibrated power meter (Field Master, Coherent, USA). The control

Table 1- Materials used in this study, manufacturer, batch number and shade of the material

\begin{tabular}{llll}
\hline $\begin{array}{l}\text { Materials and Light } \\
\text { curing units }\end{array}$ & \multicolumn{1}{c}{ Manufacturer } & Shadeh \# \\
\hline Enforce - catalytic & Dentsply, Rio de Janeiro, Brazil & 67966 & - \\
Enforce - base & Dentsply, Rio de Janeiro, Brazil & 68390 & B1 \\
Duceram ceramic & Ducera Dental GMbh \& Co.KG & $0878 / 13$ & B3 \\
Ultraled $\left(130 \mathrm{mw} / \mathrm{cm}^{2}\right)$ & Degussa Dental, Germany & $1051-5$ & - \\
XL $2500\left(760 \mathrm{mw} / \mathrm{cm}^{2}\right)$ & 3M, Sumaré, SP, Brazil & 3000165 & - \\
\hline
\end{tabular}


groups (G3A, G3B, G3C, G4A, G4B and G4C) were performed in the same way, however without interference of the ceramic disc. Each group contained five specimens. Thereafter, the specimens were stored in distilled water in a light-proof container at $37^{\circ} \mathrm{C}$ for 24 hours and hardness was measured using a Vickers indentor.

\section{Hardness evaluation}

The microhardness of the specimens was obtained using the mhp 160 Microhardness Tester (Carl Zeiss, JENA, Japan) with a marker for Vickers units. The hardness value (VHN) was obtained on the top (surface near the light source) and bottom surfaces (surface far from the light source). One indentation was made on the central part of each sample on both sides and two readings were taken from each indentation. These indentations were made with a 30-g load for 30s and the hardness values were obtained after deloading. These values were then averaged for the five samples to obtain a mean top surface value and a mean bottom surface value.

Data were submitted to four-way ANOVA and Tukey multiple comparison tests.

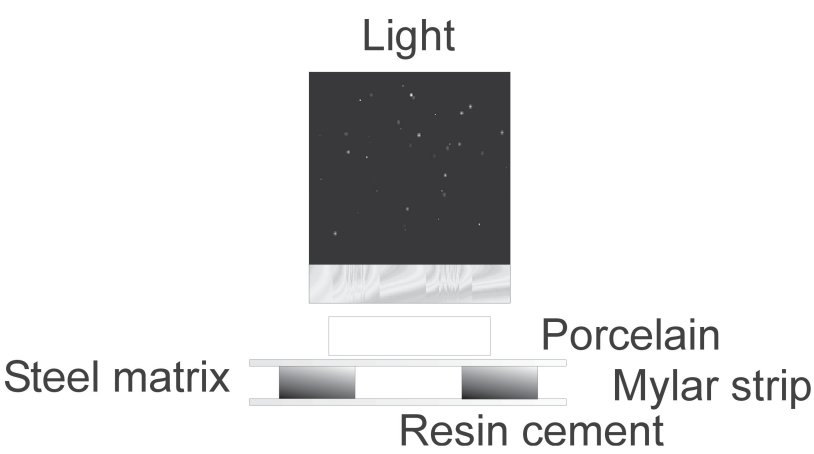

FIGURE 1- Diagram of the experimental set-up used for polymerization of resin cement through ceramic disc

\section{RESULTS}

The mean hardness values for the top and bottom surfaces for different exposure times and light-curing sources are shown in Table 2. Four-way ANOVA exhibited interactions between exposure times, presence of ceramic, light source and location (top or bottom) ( $\mathrm{F}=3.845$ and $\mathrm{p}=0.024)$. Thus, multiple comparisons were performed using Tukey tests at $\mathrm{p} £ 0.05$.

In general, the hardness observed on the top surface of all groups was higher than that for the bottom, however, only in group 3A (control, HL, 60s), this difference was statistically significant, which was due to a critical value determined by analysis.

In the same way, the hardness on the top surface in control groups (light-curing of the resin cement without ceramic disc) provided by the QTH unit was higher than Ultraled, demonstrating significant differences only between groups 3A (top surface) and 4B (top surface), for which the hardness produced by the QTH unit (60s) was significantly higher than that yielded by LED (80s).

In experimental groups, considering the top surfaces, the hardness produced by LED in groups 2A(60s), 2B (80s) and 2C (120s) did not show statistically significant differences between them. In the same way, in group 1 (HL), the three exposure times (60s, 80s and 120s) showed similar hardness. However, in group 2A (LED, 60s), hardness was significantly lower than groups 1A (HL, 60s), 1B (HL, 80s), 1C (HL, 120s) and 4A (control, LED, 60s). Using LED for 80s and 120s, the results were statistically similar to groups $1 \mathrm{~A}$ (HL, 60s), 1B (HL, 80s) and their controls (G4B and G4C). The highest hardness values in experimental groups were obtained in group 1C (HL, 120s), and statistically superior to groups with LED. Only in this group (1C) hardness was comparable with the respective control (3C). The bottom surfaces data are important to analyze in order to know whether deeper areas of the resin cement are also adequately

TABLE 2- Vickers Hardness numbers (VHN) and standard deviations (SD) of Enforce dual-cured cement

\begin{tabular}{|c|c|c|c|c|c|c|c|c|c|c|c|c|}
\hline \multirow[b]{2}{*}{ Group } & \multicolumn{6}{|c|}{ QTH ligth (conventional) } & \multicolumn{6}{|c|}{ LED light } \\
\hline & \multicolumn{2}{|c|}{$1 A-60 s$} & \multicolumn{2}{|c|}{$1 B-80 s$} & \multicolumn{2}{|c|}{$1 C-120 s$} & \multicolumn{2}{|c|}{$2 A-60 s$} & \multicolumn{2}{|c|}{$2 \mathrm{~B}-80 \mathrm{~s}$} & \multicolumn{2}{|c|}{$2 c-120 s$} \\
\hline & Top & Bottom & $\mathrm{T}$ & $\mathrm{B}$ & $\mathrm{T}$ & B & $\mathrm{T}$ & B & $\mathrm{T}$ & B & $\mathrm{T}$ & $\mathrm{B}$ \\
\hline \multirow[t]{2}{*}{ Experimental* } & 45.5 & 40.7 & 42.3 & 44.3 & 49.1 & 45.8 & 32.7 & 26.8 & 40.5 & 33.0 & 39.2 & 37.5 \\
\hline & $(2.2)$ & $(3.0)$ & $(1.6)$ & $(5.4)$ & $(2.5)$ & (3.1) & (3.4) & (3.2) & (2.3) & (2.7) & (1.9) & $(4.3)$ \\
\hline \multirow[t]{2}{*}{ Group } & \multicolumn{2}{|c|}{$3 A-60 s$} & \multicolumn{2}{|c|}{$3 B-80 s$} & \multicolumn{2}{|c|}{$3 c-120 s$} & \multicolumn{2}{|c|}{$4 A-60 s$} & \multicolumn{2}{|c|}{$4 \mathrm{~B}-80 \mathrm{~s}$} & \multicolumn{2}{|c|}{$4 C-120 s$} \\
\hline & Top & Bottom & $\mathrm{T}$ & $\mathrm{B}$ & $\mathrm{T}$ & B & $\mathrm{T}$ & B & $\mathrm{T}$ & B & $\mathrm{T}$ & $\mathrm{B}$ \\
\hline \multirow[t]{2}{*}{ Control** } & 55.7 & 46.7 & 54.3 & 46.9 & 52.4 & 49.7 & 48.8 & 42.5 & 46.8 & 45.2 & 48.5 & 46.1 \\
\hline & (3.9) & $(4.5)$ & (1.6) & (2.2) & $(4.0)$ & (3.5) & (1.2) & (6.0) & (3.8) & (2.5) & (4.0) & (4.0) \\
\hline
\end{tabular}

*Experimental: light-curing with ceramic interposition

${ }^{*}$ Control: light-curing with no ceramic interposition 
cured. In these surfaces, the hardness produced by LED in group 2A (60s) was similar to group 2B (LED, 80s), but significantly lower than other groups tested. The group 2B (LED, 80s) was comparable with group 1A (HL, 60s) and the group 2C (LED, 120s) was similar to groups 1A (HL, 60s) and $1 \mathrm{~B}$ (HL, 80s). In group 1 (HL) the three exposure times (60s, 80s and 120s) also showed similar hardness in bottom surfaces and the group 1C (HL, 120s) was significantly harder than LED groups.

\section{DISCUSSION}

LED units are considered as an alternative to QTH units for light-curing of resin materials which contain photoinitiators with an absorption spectrum between 450$500 \mathrm{~nm}^{8,10,13,16,21}$. Rather than a hot filament, as used in halogen bulbs, LED technology uses junctions of doped semiconductors (InGaN- gallium nitride) for the generation of light ${ }^{10,21}$. Although LED units generally present a lower intensity than conventional QTH units, $100 \%$ of the energy emitted by blue LED lies within the spectrum of camphorquinone $^{10,21}$. In contrast, almost $80 \%$ of the total energy of QTH units is outside the useful curing range ${ }^{10}$.

Blue LED technology has been studied for light-curing of direct resin restorations and was considered viable in these clinical situations $8,10,13,16,21$. However, this study evaluated an important condition, where the hardness of the Enforce resin cement was determined after light-curing through the ceramic disc by a QTH unit and by an Ultraled. This situation is a common clinical procedure involving ceramic inlays, onlays and crown restorations. There are many factors that affect the light transmission in indirect restorations such as ceramic thickness, exposure time and intensity of the light source ${ }^{3,11,12}$. Thus, it is very important to the practitioner to know if the LED unit is viable for lightcuring of indirect restorations. The hardness test is useful to determine depth of cure and it is an important indirect way to verify the light source efficiency ${ }^{6,7}$.

The data obtained in control groups (photo-curing without ceramic disc) confirmed that Ultraled is comparable to conventional QTH unit since, in general, there were no significant differences between them. These findings are in accordance with other works ${ }^{8,13,16,18,21}$, which stated that the LED generates similar depths of cure as conventional QTH units in resin composite specimens.

However, in experimental groups where the resin cement was light-cured through an obstacle (ceramic), the Ultraled working with 60s of exposure time, which is generally recommended to reach an adequate polymerization of the cement $^{11,12}$, produced a significantly lower hardness than conventional QTH unit and its correspondent control group. Although the LED unit emits $100 \%$ of the energy within the spectrum of the camphorquinone ${ }^{10}$, this finding can be explained by the reduced intensity of the light emitted by Ultraled used $\left(130 \mathrm{~mW} / \mathrm{cm}^{2}\right)$. Nagel ${ }^{14}$ stated that the intensity of a light within a given spectral range is a measure of the number of photons emitted and that an isolated photon emitted at $470 \mathrm{~nm}$ by a light source with reduced power density has the same energy when compared to another photon at 470nm emitted by a light source with high power density. Thus, when the LED light needs to cross any obstacle, the results achieved in this study demonstrated that longer exposure times are required in comparison with the QTH unit, which had higher hardness values. The 80s and 120s exposure times used with Ultraled were comparable with the halogen groups with 60s and 80s and their control groups. Thus, an increase of at least $33 \%$ of the curing time with Ultraled is necessary to reach results similar to QTH unit (60s and 80s) with this type of ceramic. The increase in exposure time is an important requirement for the practitioners when light-curing indirect restorations with first-generation LED units.

The discussion was pointed to resin cement thickness generally found in margins of indirect restorations (50 - 100 $\mathrm{mm})^{17}$, because those results correspond to the top surface of the samples. However, in most indirect systems, the fabrication process leaves a uniform space between crown and teeth above the marginal area, leading to a better adjustment and producing space for resin cement. In this aspect, LED was also insufficient with 60s of exposure, compared with QTH groups in bottom surfaces. Based on the results in these surfaces (bottom), in greater thickness layer of the resin cement, the 120s of exposure time using Ultraled is expected to be a better option than 80s because the former was statistically similar to halogen groups with 60 s and 80s.

The differences between top and base hardness that occurred after 24 hours in a dual-cured material is related to the reduction of light intensity across the specimen. According to Pilo; Cardash ${ }^{18}$ the hardness ratio between these surfaces should not exceed $20 \%$ for visible light-cured composites to be considered adequately polymerized. Hence, the results of this study demonstrated for all groups a hardness ratio $=0.8$. However, when comparing bottom surfaces of the experimental groups and top surface of the respective control groups, the hardness ratio was $=0.8$ for groups $1 \mathrm{~A}(0.73=40.7 / 55.7)$; $2 \mathrm{~A}(0.54=26.8 / 48.8) ; 2 \mathrm{~B}(0.70=$ $33.0 / 46.8)$ and $2 \mathrm{C}(0.77=37,5 / 48.5)$, thus requiring longer activation periods especially for the first generation LED units. On the other hand, it must be considered that resin cement presents the chemical reaction that could compensate for the absence of light in deep areas, but the curing process is continuous and the chemical elements responsible to the activation of the resin material can be present in low concentration.

The data of this study complement the existing literature about blue LED technology $\mathrm{y}^{10,15,16,19}$ and therefore, has a great potential in clinical applications. However, the new generations of LED units with higher power density are a better option for polymerization of resin cement under indirect restorations instead to increase the exposure time.

The Ultraled requires at least 80 s of exposure time to be comparable to 60s of halogen curing time. However, in thick resin cement layers, 120 s of exposure time should be recommended for light-curing of conventional ceramic 
indirect restorations with LED. Therefore, the LED unit can be viable for light-curing of indirect restorations.

\section{ACKNOWLEDGEMENTS}

We would like to thank Dr Vanderley. S. Bagnato and Marcello R. B. Andreeta of São Carlos Institute of Physics for the productive collaboration. The authors are grateful to Nelson Queiroz for technical support. This study was supported by a grant from CNPq.

\section{REFERENCES}

1- Bouschlicher M. Visible light-curing. J Esthet Rest Dent 2001;13:16-7.

2- Breeding LC, Dixon DL, Caughman WF. The curing potential of light-activated composite resin luting agents. J Prosthet Dent 1991;65:512-8.

3- Chan KC, Boyer DB. Curing light-activated composite cement through ceramic. J Dent Res 1989;68:476-80.

4- Cook WD. Spectral distributions of dental photopolymerization sources. J Dent Res 1982;61:1436-8.

5- Davidson CL, De Gee AJ. Light-curing units, polymerization, and clinical implications. J Adhesive Dent 2000;2:167-73.

6- De Wald JP, Ferracane JL. A comparison of four modes of evaluation depth of cure of light-activated composites. J Dent Res 1987;66:72730 .

7- Ferracane JL. Correlation between hardness and degree of conversion during the setting reaction of unfilled dental restorative resins. Dent Mater 1985;1:11-4.

8- Frentzen M, Föll V, Braun A. Photopolymerization of composite resin using LED technology. J Oral laser Applications 2001;1:18994.

9- Hasegawa EA, Boyer DB, Chan DCN. Hardening of dual-cured cements under composite resin inlays. J Prosthet Dent 1991;66:18792.

10- Kurachi C, Tuboy AM, Magalhães DV, Bagnato VS. Hardness evaluation of a dental composite polymerized with experimental LED-based devices. Dent Mater 2001;17:309-15.

11- Lee IB, Um CM. Thermal analysis on the cure speed of dual cured resin cements under ceramic inlays. J Oral Rehabil 2001;28:186-97.

12- Linden JJ, Swift Jr. EJ, Boyer DB, Davis BK. Photo-activation of resin cements through porcelain veneers. J Dent Res 1991;70:154-7.

13- Mills RW, Jandt KD, Ashworth SH. Dental composite depth of cure with halogen and blue light emitting diode technology. Brit Dent J 1999;186:388-91.

14- Nagel R. Operation and diagnostic features of the VIP light. Comp Cont Educ Dent 1999;20:55-9.

15- Nomoto R. Effect of light wavelength on polymerization of light-cured resins. Dent Mater J 1997;16:60-73.
16- Nomura Y, Teshima W, Tanaka N, Yoshida Y, Nahara Y, Okasaki M. Thermal analysis of dental resins cured with blue light-emitting diodes (LEDs). J Biom Mater Res 2002;63:209-13.

17- Özcan M, Pfeiffer P, Nergiz I. Marginal adaptation of ceramic inserts after cementation. Oper Dent 2002;27:132-6.

18- Pilo R, Cardash HS. Post-irradiation polymerization of different anterior and posterior visible-light-activated resin composites. Dent Mater 1992;8:299-304.

19- Price RB, Felix CA, Andreou P. Evaluation of a secondgeneration LED curing light. J Can Dent Assoc 2003; 69:666.

20- Rueggeberg FA, Ergle JW, Mettenburg DJ. Polymerization depths of contemporary light-curing units using microhardness. J Esthet Dent 2000;12:340-9.

21- Stahl F, Ashworth SH, Jandt KD, Mills RW. Light-emitting diode (LED) polymerization of dental composites: flexural properties and polymerization potential. Biomater 2000;21:1379-85.

22- Trevor Burke FJ. Fracture resistance of teeth restored with dentin-bonded crowns constructed in a leucite-reinforced ceramic. Dent Mater 1999;15:359-62.

23- Yap AU, Wattanapayungkul P, Chung SM. Influence of the polymerization process on composite resistance to chemical degradation by food-simulating liquids. Oper Dent 2003; 28:723-7. 